\title{
Studies on the Substructures of the Lysozyme-rich Secretory Granule of the Serous Cell in the Human Nasal Gland
}

\author{
Mitsuo Machino, ${ }^{1}$ Hiroyuki Morioka, ${ }^{2}$ Masayoshi Tachibana, \\ Takashi Tsuruoka and Osamu Mizukoshi ${ }^{1}$ \\ Department of Otorhinolaryngology (Prof. O. Mizukoshi) ${ }^{1}$ and Laboratory of Electronmicroscopy \\ (Director: Dr. H. Morioka), ${ }^{2}$ Kyoto Prefectural University of Medicine, Kyoto, Japan
}

Received March 28, 1984

\begin{abstract}
Summary. Using a protein A-gold immunohistochemical technique, the lysozyme rich core and the lysozyme free peripheral rim were differentiated in the secretory granule of the serous cell in the human nasal mucosa, under the electronmicroscope. The shperical lysozyme rich core, which had been excreted into the gland lumen, was also wrapped with the peripheral rim. This finding suggests that the peripheral rim defends the integrity of the core and inhibits the release of lysozyme from the core.
\end{abstract}

It has been elucidated that the central core of the serous cell granule is rich in enzymes such as pepsinogen (Zeitoun et al., 1972) and lysozyme (Bowes and Corrin, 1977; TACHiBAnA et al., 1984). This paper deals with the function of the peripheral rim in regard to one of these enzymes (lysozyme) in the central core of the serous granule in the human nasal gland.

\section{MATERIALS AND METHODS}

The method will be described elsewhere (TAchibana et al., 1985). In short, human nasal mucosa of the inferior turbinate was obtained surgically. Specimens were fixed in $1 \%$ glutaraldehyde in $0.1 \mathrm{M}$ phosphate buffer, $\mathrm{pH} 7.4$ for $2 \mathrm{hr}$ at $4^{\circ} \mathrm{C}$. After fixation, tissues were rinsed with the same buffer, dehydrated with ethanol and embedded in Epon. Ultrathin sections were mounted on nickel grids. Sections were incubated with $1 \%$ ovalbumin in phosphate-buffered saline $(\mathrm{pH} 7.4)$ for $5 \mathrm{~min}$ at room temperature, then with goat antiserum to human lysozyme (diluted 1:400-4,000) and for control with antiserum previously absorbed by the antigen for $48 \mathrm{hr}$ at $4^{\circ} \mathrm{C}$, and finally with the pAg (protein A-gold) solution (RoTH, 1982) for $30 \mathrm{~min}$ at room temperature. The sections were stained with uranyl acetate and lead citrate before observation. 


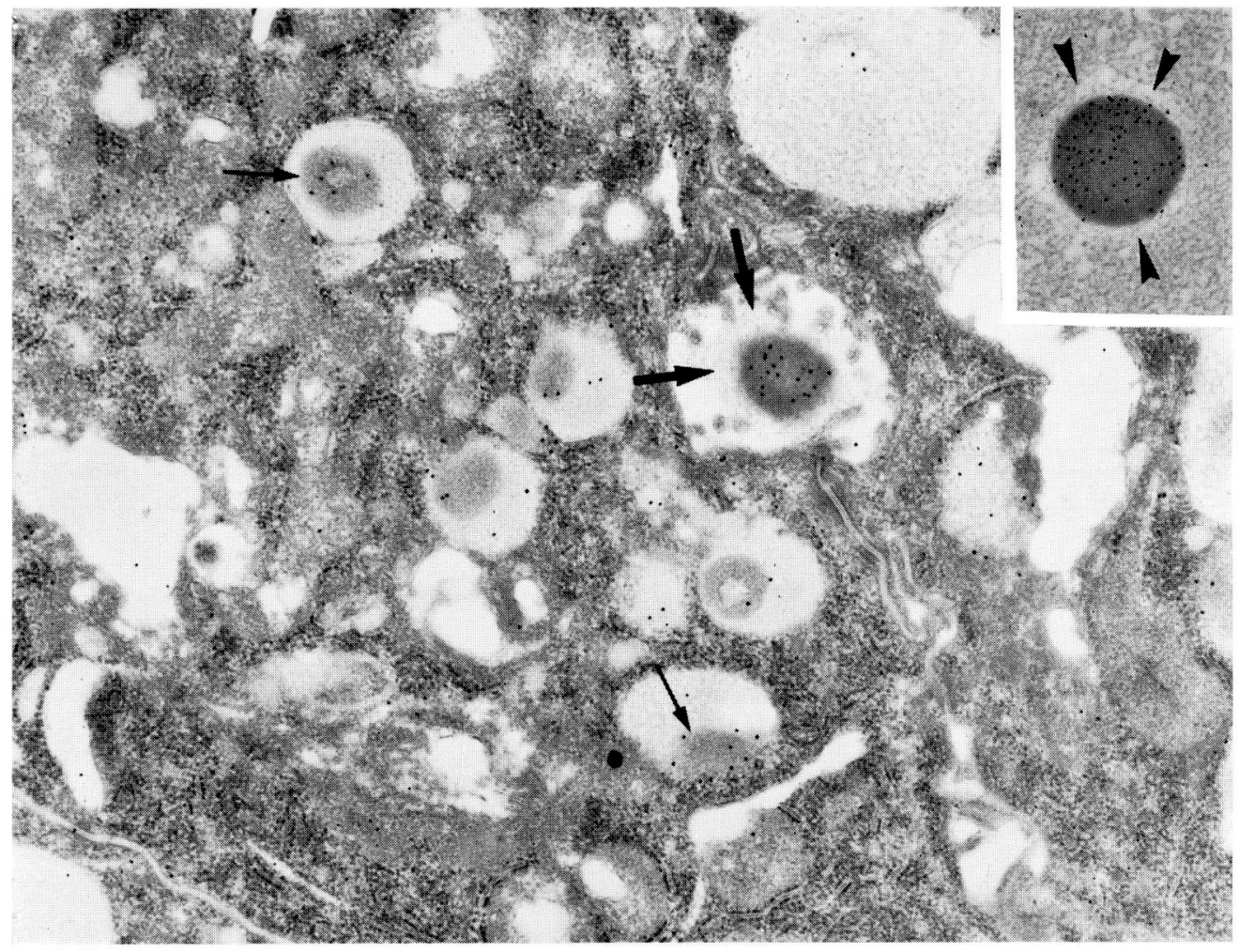

Fig. 1. Electron micrograph of a serous cell in human nasal mucosa. The secretory granules reveal a central core with high electron density and peripheral rim with low electron density. pAg deposition is dominant on the central core of the granules (small arrows). Also on the central core secreted into the intercellular canal, the pAg deposition is intense (large arrows) and around the core in the canal the peripheral rim persists without any limiting membrane. (Anitiserum diluted, 1:2,000). $\times 21,000$. Inset. A secreted central core in a large lumen of the gland. Remnant of peripheral rim is noted between the central core with much pAg particle deposition and heterogeneous substance in the gland lumen (arrowheads). (Antiserum diluted $1: 2,000) . \quad \times 21,000$

\section{RESULTS AND DISCUSSION}

In the serous cell of the human nasal gland, secretory granules were conspicuous (Fig. 1). These granules were membrane limited, ovoid in shape and measured 400-1,000 nm in diameter. The matrix of the serous secretory granule revealed two substructures: a central core and peripheral rim. The central core with high electron density was located centrally or eccentrically in the matrix of the granule. An electron lucent peripheral rim of varying thicknesses enveloped the central core.

Protein A-gold $(\mathrm{pAg})$ particles were densely deposited on the central core of serous granules in the cytoplasm but not on the peripheral rim of the granules (Fig. 1, small arrows). In the intercellular canalicule and in the larger lumen of the gland, an extruded serous secretory granule without a limiting membrane was observed. "Without limiting membrane" means that the matrix of the secretory granules was extruded to the outside of the cell through the mechanism classically called exocytosis (NAGASAWA, 
1977). pAg particles were also densely deposited on the central core of extruded serous granules, but the surrounding "halo" was devoid of pAg particles (Fig. 1, large arrows and inset, arrow heads).

The central core and the peripheral rim are generally accepted as substructures of a serous sacretory granule. The central core of the serous granule was described as being rich in proteins (ICHIKAWA and IcHIKAWA, 1977), such as pepsinogen (ZEITOUN et al., 1972). On the other hand, the peripheral rim has revealed mucosubstances (SPICER, 1965) or sialomucins (Quint aRELli et al., 1964; IchiKawa and IchiKawa, 1977). Thus the peripheral rim seems to constitute a mucinous envelope for the protein-rich central core (ICHIKAWA and IchIKAWA, 1977). The present results showing that the antigenic site of lysozyme was found on the central core but not on the peripheral rim confirms the above mentioned relationship.

A salient point of the finding is that some serous secretory granules, if not all, which are extruded by way of exocytosis are likely to keep this central core-peripheral rim relationship in the extracellular space. The halo observed around the granules (Fig. 1. inset) in varying thicknesses is most likely identical to the remnant of the peripheral rim. The mucinous peripheral rim may play a role in protecting the central core from disintegration and in inhibiting the release of lysozyme, and possibly various other enzymes also, out of the central core.

\section{REFERENCES}

Bowes, D. and B. Corrin : Ultrastructural immunocytochemical localization of lysozyme in human bronchial glands. Thorax 32: 163-170 (1977).

Ichikawa, M. and A. Ichikawa : Light and electron microscopic histochemistry of the serous granules in the salivary glandular cells of the Mongolian gerbil (Mongolian meridianus) and rhesus monkey (Macaca irus). Anat. Rec. 189: 125-140 (1977).

Nagasawa, J : Exocytosis: the common release mechanism of secretory granules in glandular cells, neurosecretory cells, neuron and paraneurons. Arch. histol. jap. 40, Suppl.: 31-47 (1977).

Quintarelli, G., J. E. Scott and M. C. Dellovo: The chemical and histochemical properties of alcian blue. II. Dye binding of tissue polyanions. Histochemie 4: 86-98 (1964).

Roth, J.: The preparation of protein A-gold complexes with $3 \mathrm{~nm}$ and $15 \mathrm{~nm}$ gold particles and their use in labelling multiple antigens on ultrashin sections. Histochemie 14: 791-801 (1982).

Speicee, S. S.: Diamine methods for differentiating mucosubstances histochemically. J. Histochem. Cytochem. 13: 211-234 (1965).

Tachibana, M., H. Morioka, T. Tsuruoka, M. Machino and O. Mizukoshi : Ultrastructural localization of lysozyme in the human nasal gland by protein A-gold technique. Acta histochem. cytochem. (1985, in press)

Zeitoun, P., N. Duclert, F. Liautaud, F. Potet and L. Zylberbeng: Intracellular localization of pepsinogen in guinea pig pylonic mucosa by immunohistochemistry. Lab. Invest. 27: 218-225 (1972).

町野満夫

干602 京都市上京区河原町通広小路

京都府立医科大学

耳鼻咽喉科学教室
Dr. Mitsuo Machino

Department of Otorhinolaryngology

Kyoto Prefectural University of Medicine

Kawaramachi-Hirokoji, Kamikyo-ku

Kyoto, 602 Japan 